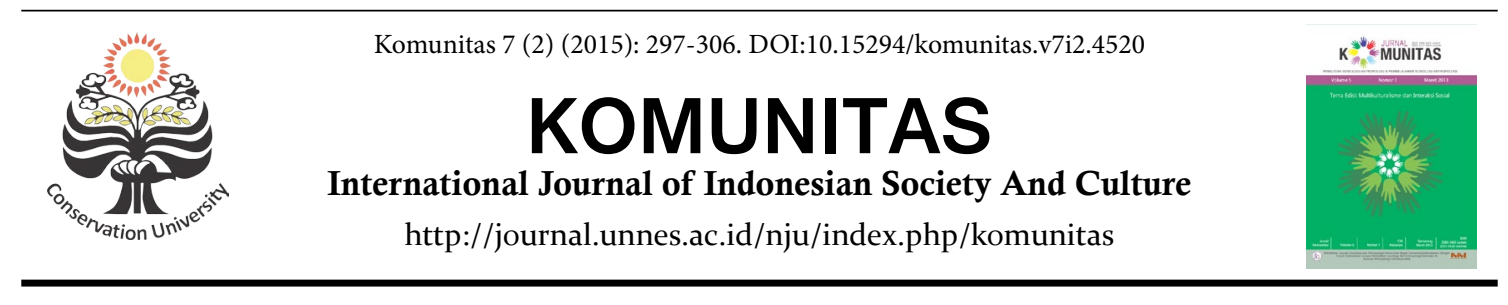

\title{
Papalele: Dangerous Encounter and Transaction in Conflict
}

\author{
Simon Pieter Soegijono ${ }^{1 凶}$ \\ ${ }^{1}$ Lecturer in Faculty of Economics, Christian University of Indonesia Maluku - Ambon
}

Permalink/DOI: http://dx.doi.org/10.15294/komunitas.v7i2.4520

Received : August 2015; Accepted: September 2015; Published: September 2015

\begin{abstract}
The true peace is still being fought in various countries, especially Indonesia. Diversity has apparently become the main challange. Therefore, it is important to raise the individual and community awareness to pluralism. Because of that, building peace becomes an important factor for any country with various identities such as Indonesia. This peace is related to some values, including: mutual respect and a sense of tolerance to face the conflict of religion, ethnicity, and race which happens right now. Recently, there are numerous attempts that have been done by government, education institution, non-governmental organization, and others independent stakeholders to overcome the conflicts. The strategy of peace recovery can be done by formal activities, such as: workshops, trainings, seminars, focus group discussions, etc. However, the results do not show any significant progress. In spite of the efforts to build peace, this research paper provides an idea and contribution to peace building on the empirical and informal level that has been established by micro business in Ambon City. They are known as papalele. Papalele gives an essential lesson about peace from economic activity; without religion, ethnicity, and race. However, their role is not considered seriously by various stakeholders at that time and became an untold story in peace building in Ambon City, although in fact, they are the true peace bridges.
\end{abstract}

Keywords: identity; trust and social capital

\section{INTRODUCTION}

Conflicts which occur between two groups of Muslim-Christian communities ${ }^{1}$ in 1999 until 2003 have a significant impact for the people of Ambon (Duncan 2005). The conflicts practically separate them based on each group lines. The conflict between two communities has become a very severe physical conflict and led so many casualties as well as property loss. The conflict which occurred in several months has claimed thousands of lives and the destruction of physical structures.

\footnotetext{
1 Pariela Tony. D (2008) explains the different perspective and understandng about the root of conflict in Maluku. This difference happens both in local and national levels. Is Maluku conflit a religion conflict or a political conflict which is swayed to religion issue? Beside those discussions, there is not any valid study on the root of Maluku conflict.

Corresponding author:
Address:
Email : petersoegijono@gmail.com
}

Telp
May 1999, since the conflict hit the city of Ambon, there were approximately 3,783 households or 15.941 people from all corners of Ambon who lost their property and fled away $^{2}$. As a result of the conflict, there were 55 refugee camps in various locations. The data from the police of Ambon and Lease island mention that during the year 19992000, the conflict in Ambon city destroyed: 4,938 units of houses, 1158 Home-Stores (offices), 11 school buildings, 21 government buildings, 10 private offices , 4 hotels, 4 bank offices, and 3 military barracks. And there were 508 civilians and 20 security officers who became victims and died in vain ${ }^{3}$. To accommodate the displaced people, Churchs and Mosques became the shelters, considering both of this worship places are safe

2 Kompas Newspaper, 5 May 1999.

3 Tempo Newspaper 20 February 2000.

(c) 2015 Semarang State University. All rights reserved p-ISSN 2086 - 5465 | e-ISSN 2460-7320 
from the rage. In fact, those two places were no longer able to accommodate civilians to save themselves because of the conflict.

The negative implications became more severe as the conflict destroyed the economic infrastructures (Adam 2008). At the center of Ambon, there were three locations of markets namely Belakang Kota Market (old market), Mardika Market, and Batu Merah Market. Two of the three markets were destroyed because of the conflicts. The markets as a means of economic activities were burned and destroyed. Therefore, they practically could not be used. The destruction of the markets resulted in scarcity of food and clothing due to disturbed distribution of goods and services.

The difficulty was really encountered by the people in both sides because of the scarcity of needs. The supply of goods was hampered and delayed. The factors of personal safety and security from the organizers of air, sea, and land transportations were the major cause. They did not dare to take risks to supply the goods. Both groups of people who lived side by side as brothers for decades were destroyed in a minute during the riots (Adam and Peilouw 2008; Sholeh 2013). The power of togetherness which became social institutions of 'pela-gandong's was no longer able to be a medium to bridge the conflict.

Therefore, we will examine papalele to illuminate about the complex relationship between identity and social capital. This study is important in the way it relates to social capital in conflict area identity and social capital. These two perspectives of science are at least able to confirm the role of papalele to build their version of peace process. Indeed, sometimes, strengthening the legitimacy of self-identity as a group can strengthen social capital, and vice versa. In this position, we will explain that social capital strengthens identity as well.

Identity is sometimes regarded as so-

4 Social system in Maluku emphasizes the relation based on geneology, cultural values because of bloodline relationship among people or groups (village). Pela Gandong can also happen because of a conflict or war, and particular event which benefits for both parties or vice versa. mething that just happens naturally, but it is difficult in practice (Pilokoanu 2010). Getting a sense of identity is very dependent on an empirically measuring instrument. Similarly, this applies to the identity which is used to interpret the phenomenon as a symbol as well as the behavior of individuals in the group and behavior when building relationships with others. Although, the concept of identity is not always familiar to be used in the economic area (Davis 2006).

Identity is a central concept in the social science (Abdelal et al. 2001; Chen and $\mathrm{Li}$ 2005). By looking at the identity of trader activity, it is easy to characterize identity of someone through behavior. However, it does not mean that the views of relevant theoretical identities are not discussed. By referring to the theory of identity, we can grasp the meaning of identity, but cannot justify the identity.

An understanding of identity is a common phenomenon, demonstrated through performance or construction which is interpreted by others (Benwell and Stokoe 2006). The membership of social identity occurs because it has causal relationship of actions and behaviors (Benwell and Stokoe 2006). Identity characterizes an individual based on many positions and roles within society, and it is important to note that both individual and society are also closely related to the concept of identity (Burke and Stets 2009). Ashton argues (Jenkins 2008; Pilokoanu 2010) that it is addressed to know who we are, and how we know the other people, other people know who we are, we know what they think about us, and so on-a multidimensional classification or mapping the world where humans live in it as individuals and also as group members. It means that identity can be observed in everyday life and can be verified (Berger and Lukcman 1990).

Generally, the identity which is often spoken in the field of psychology departs from the view of Herbert Blumer. Blumer created and coined the term symbolic ${ }^{5}$ in-

5 Generally, the basic principles of the symbolic interaction theory are: first, unlike the lower animals, humans are supported with the ability to think, secondly, the ability to think is shaped by social interactions, third, 
teraction term in 1962 and then expanded again in 1969. Blumer himself steeped in the interpretation of the thought of George Herbert Mead to show the perspective that focused on the unique character of human interaction centered on the use of symbols. Symbol systems can be used to represent objects and events in certain situations even when the objects and events are not physically present, including words that are used to communicate (Ritzer 2004; Jenkins 2008).

Therefore, in any system of identity construction, there is a hierarchy of norms, as a reciprocal relationship to measure the behavior or judgment. Without value hierarchy, which also may be hidden in the mind, we cannot find collectivity to face new challenges. This construction system can be found in one study in Germany. Casey and Dustmann (2009) present the identity associated with the process of immigrants move in to other countries by including the identity of their country of origin. The identity is closely related to the economic development of individuals, the labor market (Loveband and Young 2006).

From the perspective of identity that has been described above, we can get an idea that the real identity is a subjective reality. An objective circumstances which then gets meaning. As noted by Berger and Luckman (1990).

Identity, by itself, constitutes a key element of subjective reality, and as all subjective reality, dialectically related to the community. Identity is shaped by social processes. So, after gaining its form, it is main-

in social interaction people learn the meanings and symbols that allow them to use the ability to think, fourth, meaning and symbol let people take typical action and interaction of humans, fifth, people are able to modify or alter the meaning and symbols that they use in the actions and interactions based on their interpretations on the situation, sixth, people are able to make modifications and changes mostly because of their ability to interact with themselves which allows them to think of possible actions, exploring their relative strengths and weaknesses, and then choose, seventh, interwoven patterns of action with this interaction then create groups and society (Ritzer 2008). tained, modified, or even reshaped by social relations (Widén-Wulff and Ginman 2004). Social processes involved in forming and maintaining the identity is determined by social structure. On the contrary, the identity which is generated by the interaction between organisms, individual awareness, and social structures that have been given, maintain, modify, or even reshape ${ }^{6}$.

From this view, we can understand that people actually will not be separated from society as a social environment. Both are bound to each other, interact with each other. Or it could be said that the individual influences society through actions, and vice versa, society binds individual communities through the rules and the value of certain norms.

At this stage, the debate about the true identity depends on which side we interpret its own identity. The understanding on identity is a step to justify this phenomenon or at least to be able to identify it. With the identity of that debate, I argue that the real identity is an individual act which is based on the preference and background owned in a social environment. The action is supported by a set media or tools as symbols to distinguish between individuals and groups of individuals and other groups. Similarly, papalele as individuals and also as a group have social identity attached to them. In addition to having a certain medium, they have a common view in the business and have a collective consciousness as a form of identity. At the same time, other people also have to justify them as a group or a particular business community (Inkpen and Tsang 2005).

In this position, papalele has identified identity ${ }^{7}$ through self-defense mechanism

6 Berger Peter. L dan Luckman Thomas, 1990 "Tafsir Sosial Atas Kenyataan: Risalah tentang Sosiologi Pengetahuan". Publisher PT Pustaka $\mathrm{LP}_{3} \mathrm{ES}$ Jakarta.

7 Manuel Castlle (Putranto, 2008) gives the picure on identity through; (a), meaning sources and experience of people, (b), process of meaning construction which is based on cultural attributes which are prioritized over the other meaning sources, (c), identty is plural and not singular; (d), identity is not the same as role or a set of roles. Identity functions 
for long term. The self-defense mechanism can be referred as resistance identity, as the view of Castlles Manuel (1997):

\begin{abstract}
"Resistance identity is generated by those actors who are in positions/ conditions devalued and/or stigmatized by the logic of domination, thus building trenches of resistance and survival on the basis of principles different from, or opposed to, those permeating the institution of society".
\end{abstract}

Castlle explains that the resistance identity is an effort which is raised by the actor to make the perimeter when he/she is under the pressure (Pilokoanu 2010).

Meanwhile, social capital is very prominent for papalele in every activity. Indeed, in terms of the theory of social capital, it is still debatable. However, the theories of social capital still serves as the consumption for academic community, bureaucrats, and various circles and is used as a tool to analyze and dissect the process of development with regard to social relations, economics of community development. Even the concept of social capital has become a complement as other concepts such as human capital, physical capital, financial capital, manufacturing capital, and natural capital (Porritt 2002 $)^{9}$. Therefore it is important to understand the theoretical perspective of social capital to work in the community or in a group or individual perspective.

In the development of the use of concept on social capital, it turns out not only as an economic approach, but it has evolved

to manage meanings, while role manages functions, (e), group of identity is meaning sources for the actor which are deconstructed by process of individualization; (f) identity is related to the internalization process of values, norms, goals, and ideals; (g), naturally, identity can be classified into two, namely individual and collective identities. Individualism can also be collective identity; (h), there are three forms and origins of identity, namely: legimitation identity, resistancy identity, project identity.

8 Castlle Manuel, 1997 "The Information Age: Economy, Society and Culture. II. The Power of Identity". Oxford UK, Blackwell Publisher.

9 As stated by Grootaert (2002) there are three types of capitals, namely: natural capital, physical (produced) capital, and human capital which are often used for economy development analysis and process. in various disciplines such as law, political science, sociology and anthropology (CRP, 2003). These developments result in the emergence of various opinions and ideas that often lead to a serious debate about the use of the concept on social capital ${ }^{10}$. Therefore, it is better that the social capital can be raised by some experts as referred to in this article. Such as the opinion Serageldin and Grootaert (2000):

\begin{abstract}
A variety of different entities, with two elements in common: they all consist of some aspect of social structure, and they facilitate certain actions of actors - whether personal or corporate actor - within the structure ${ }^{n}$.
\end{abstract}

Coleman explains that it is not just one entity in the social structure that facilitates an act of an individual or group, but rather more than one categories of entities which are different from the two elements in common: they all consist of some aspects of social structures, and they facilitate particular actions of the actor both individuals and institutions within a structure. And Robert Putnam (Serageldin and Grootaert 1999) states "A set of horizontal associations among people who have an effect on the productivity of the community"12.

10 The concept of social capital is used and published by The World Bank as written by Dasgupta Partha and Serageldin Ismail (200o) "Social Capital" A Multifaceted Perspective to map out several problems of development in some developing countries. Besides, the draft of The World Bank is the result of experts' views in the group Advisory Council to the Vice Presidency for Environmentally Sustainable Development. There are two definitions of social capital: (a) Social capital refers to norms, institutions and social norms which create quality social interaction within society and (b) social capital refers to norms, institutions and social norms which enable people to work together.

11 Serageldin, Ismail and Christian Grootaert, Defining Social Capital: An Integrating View" in Dasgupta, Partha and Ismail Serageldin. 1999, Social Capital - A Multifaceted Perspective, The World Bank, Washington D.C.

12 Serageldin, Ismail and Christian Grootaert, Defining Social Capital: An Integrating View" in Dasgupta, Partha and Ismail Serageldin. 1999, Social Capital - A Multifaceted Perspective, The World Bank, Washington D.C. 
Putnam differently views social capital as a set of associations that are horizontally formed between those who have an influence on the productivity of local community. Relationships that are horizontal is seen by Putnam as a force that is able to make fundamental changes, particularly when individuals and groups have specific goals to be achieved. Such relationships are not only based on limited interest, but also the mutual interests. Hence, they can be achieved with these interests. Putnam study departs from the social institutions in which there are networks, norms and trust. These relationships, he thinks, are the key to economic success and democracy.

In line with the opinion of Putnam, another idea is also proposed by Turner (2000) that in society there is a force which can bind the potential to be used for the process of economic development of society, so that the force can create and maintain social relationships and patterns of social organization. Social relation is a force that has the potential for economic development. On the other hand, Woolcock and Narayan are more directed to the norms and networks that enable communities to act together. Furthermore, Woolcock and Narayan develop a concept that is often used in a variety of empirical analysis in the field of sociology, economics and others.

The concept of Woolcock and Narayan is known as the three types of social capital: the first type is bonding social capital, which is associated with the relations between the same groups such as race, religion, and intergroup that the group will strengthen social ties to the group. The second type, bridging social capital, which refers to relations between different groups, and different groups will strengthen the ties between the groups. The third type is linking social capital, which refers to the relationships between individuals and groups in different social strata within a structure. Woolcock and Narayan's view can be said to have a correlation with activity of papalele. Bonding social capital occurs when papalele only builds relationships within the group, while cooperation between papalele with business partners; traders reinforce the bridging social capital.

Some of the above ideas underlie the different view of conclusions. However, in fact, this view leads to the ultimate goal which is the effort to build and strengthen a community / society that can develop himself and his group for efforts to develop the quality of life (Laurence 2009). Therefore, social capital actually is not done individually, but through a mutual social interaction, such as the view from Pantoja (2002) that social capital is nested in structure and not within individuals ${ }^{13}$.

Therefore, it can be said that social capital is a part that is not removed apart from the individual. Individual actions will have implications on the social relationship that lasts. Bourdieu (2001; Prabawa 2010) emphasizes the difference of social capital in the community or communities by individuals. Bourdieu explicitly defines the concept of social capital in terms of a network of relationships that can last a long time at the level of the individual (Prabawa 2010). Because of that, social capital cannot be separated and is closely related to the concept of social networking. Individuals will benefit from social capital if they are fused (embedded) in social networks that provide a state of the ongoing social relationship (Prabawa, 2010).

As already explained, in social capital, there is a measure to assess the process of social capital which can be norm, trust and network. When referring to the role of papalele, of course, trust and collaboration networks become the key aspects of sustainability and survival of businesses. Both also trigger collaboration with other parties, so it can be argued that the trust and networking become the motor of the business operation.

The above social capital is not pre-

13 Pantoja Enrique, 2002 "Qulitative Analysis of Social Capital: The Case of Community Development in Coal Mining Areas in Orissa, India”. Within Christian Grootaert and Thierry van Bastelar "Understanding ad Measuring Social Capital: A Multi-disciplinary Tool for Practitioners". The World Bank Washington D.C. 
sented itself without going through a process, but social capital is influenced by various internal and external factors (Leonard 2004). Internal factors are for example, among other organizational patterns that grow in a pattern (setting) culture of the local community such as social order related to traditional beliefs, the patterns of distribution of power in society, a pattern or system of production and reproduction as well as the values and norms (Pariela 2008). External factors are for example the influence of religion, globalization, urbanization, government policies, laws and legislation, the expansion of education, politics and government as well as universal values such as democracy, equality, freedom, and civilization (Hasbullah 2006).

Therefore, the framework of social capital is actually a point to explain and understand the conditions, the relevance and implications of actions done by papalele, especially those which are closely related to the trust in the network. Network relationships provide the foundation of trust and identity in the group closely and informal norms allowing the actors to engage in collective action in realizing their interests (Nee 1998). All matters related to decisions, commitments, agreements, solidity and solidarity and common purpose within and between groups, are not something that are made without having any particular goals. All these things are part of the process of thinking and acting rationally that lead to the goal (goal-oriented) (Soegijono 2011).

\section{RESEARCH METHODS}

This study used a qualitative research, with a case study. The case study is an umbrella term that covers allied research methods, equally collecting attention to the study around an event (Wilardjo 1994). Further said by Wilardjo (1994), this method seeks to provide honest explanation and detail about the specific case in a way that allows the reader to penetrate into what looks to the surface and also to verify the interpretation of the author by reviewing a number of objective data appropriate option which is used as the foundation to build the case study.

Further, this study focus was on the village of Hatalai District of South Leitimur, Market Mardika and Batu Merah Market in the city of Ambon. The third region, was the center of economic and social activity in the city of Ambon. Finding papalele was not difficult.

Furthermore, the unit of observation was something that was used as a source to obtain the data in order to describe or explain the unit of analysis (the unit of analysis) (Suwondo 2008; Ihalauw 2004). Papalele was as a source of information, as well as used as a unit of observation and analysis unit. Determination unit of analysis was done by using purposive sampling to determine the informant intentionally (Lin 1976).

In order to obtain valid data, the guided interview was used. Support tools for this purpose, among others, were voice recorder for interviews, documentation and analysis processes.

\section{RESULTS AND DISCUSSION}

Who is papalele? In general terms, the word 'papalele' for people in Maluku is a local term that has been known to those who sell goods. This is one form of meeting between the sellers who sell goods of daily needs usually selling fruits in the coastal region of Ambon by selling around (baronda). There are some people who also sell their goods in a particular location. This is very strongly attached in the community which is then understood that the one doing this job are the people who come from rural areas (Soegijono, 2011).

If this local term is studied from its etymology, papalele actually consists of two words papa which means 'to carry or bear' and lele which means 'roving. So papalele means "going around by carrying or roving" (Souisa 1999, p.38-39). Papalele can also be interpreted as "doing activities to buy goods, then sell them again to get a little profit" (Mailoa 2006, p.75).

The results show and describe the struggle of papalele during troubled condition of Ambon City (conflict). The struggle for survival was at stake at that time. That is 
what I call as a parlous meeting.

Approximately three years (19992001), Ambon City community lived based on religious lines because of the conflict. Practically, the two communities could not communicate and meet. Therefore, papalele never imagined that they would never run their business in the middle of conflict. However, for papalele, the wall between the two conflicting groups could be successfully overcome through communication and mutual trust, caring, respect and protection. The partitions were penetrated by papalele did not occur suddenly when riot atmosphere happened, but it was established long before the conflict. Therefore, the process of their interaction gained a lot of experience and stories that were untold.

When the conflict was resolved and security situation was gradually improved, papalele group was part of the society that began to open up communication deadlock between the conflicting groups. They were one of the groups of citizens who opened the deadlock of economic activity; transactions of goods and services. They created the communication between the groups, not only for economic activity but also as one of the actors of peace. At least, with the economic transactions helps to bridge up the communication deadlock.

There are some cases that illustrate the story of papalele when transacting in an atmosphere of conflict in Ambon. Papalele started trading after the escalation of violence began to decline. To keep surviving in the middle of conflict, they looked for the fruits with whatever conditions. They also traded and met people in the border lines.

The first case: three days before the conflict for the first time in 1999. Like the previous days, papalele scattered in many locations in the market. In general, they occupied the front courtyard of shops that sell a range of community needs such as clothing, shoes, sandals, grocery and so on. Rows of shops were located in the center of the market and Mardika terminal to terminal Batu Merah in Ambon City. The trading location occupied by papalele was deliberately chosen because of the crowds of people and the number of buyers. While the other Papalele often clustered in one particular location. Papalele which groups usually chose the same location so that they could help each other.

In locations around papalele, many traders did their business close to them. Generally, traders came from various tribes such as Bugis, Javanese, Makassar or other local merchants, such as from Seram Island, Kailolo Village, Pelauw Village, lease Saparua Island. Three days prior to the date of January 19, 1999 when the first conflict occurred $^{14}$, about noon, the time before the signs of abnormal conditions began to appear. They saw people and some merchants in the vicinity started to run leaving their goods. While there were also several shops on the left, right and front. They seemed to suddenly close down more quickly than usual. While still investigating the people panic, they started wondering 'what is really going on?' While continuing to pay attention to some of these people, there are busy on the phone.

Papalele looked confused when looking at behavior change of other traders around the sales outlet. Changes in the behavior of traders are visible when traders started packing merchandise or lower prices goods. While panicked people on today's market makes the most papalele began to be confused and many merchants who have to immediately leave the place to trade, so they are not necessarily running. In such conditions, the physical appearance also changes the behavior of traders in general. One trader appears to originate from the Javanese are often associated with papalele. Atmosphere of panicked traders in the market increasingly make people around him feel comfortable. Sign of the conflict in Ambon is unknown to many people. But it seems, there are some people who have expected the riots to happen, but others do not even know it at all; including papalele. Neverthe-

14 The beginning ofconflict in Ambon happened approximately at 14.30 WIT, as could be seen in Pariela Tony D, 2008 "Damai di Tengah Konflik Maluku; Preserved Social Capital Sebagai Basis Survival Strategy. Universitas Kristen Satya Wacana Salatiga. 
less, there is still mutual concern between the two such as the proximity between one papalele (Christian) with merchants from Bugis. When the atmosphere is more uncertain, the merchant from Bugis (Islam) offers services to sell goods to papalele. The merchant propose and request that papalele should immediately return home.

The second case: the experience of Habsah (57) Muslim. Long before the riots in Ambon, she always became papalele, carrying around the goods to various locations in almost the entire environment of human settlements, particularly in the predominantly Christian environment. But since the riots, she can trade in the border area. Among papalele, exchanging fruit comes from the Christian community especially local fruits like bark, harp, Gandaria, bicang (a type of mango) is important. While agricultural materials such as vegetables are produced in the territory of the Islamic community, Rumah Tiga Village, Taeno Hamlet, Hamlet, Air Ali Hamlet, and Cap Dusun Waringin, dan Desa Waiyame di Jasirah Leihitu Kecamatan Baguala

During the riots, although Mrs. Habsah was displaced in Masjid Al-Fatah ${ }^{15}$, she kept selling even though the situation did not allow. When the riots, many traders from outside the region have returned to their respective regions. Practically the number of people still trade reduced. She bought ingredients such as ginger (ginseng), basil, lemongrass, yellow (pigtails), pepper powder and some other kitchen necessities. All materials are brought to the mosque a place of refuge. Next morning around 04.00 morning, all the material is cleaned up, tied up and carried around at 06.00 am to knot the transaction to be sold to papalele derived from Christian community.

The third case: Escalation of the dispute between two groups that did not subside result in Ambon city has quite a lot of territory demarcation. Papalele and merchants usually meet in a knot particular area, the boundary conflict. Sometimes in this area often physical clash between the two groups,

15 The biggest mosque Maluku Province, located in the center of Ambon. even less so in this region often dark shootings directed to both communities. These nodes are formed naturally by the community, which then continues to grow as a place of sale between merchants.

Meet and transact at the border must be done as soon as possible for security reasons. The story of papalele transactions in this border region is very touching for $p a-$ palele like Mrs. Rina. When transacting in one location, the sound of bomb making and traders scattered and papalele run separately, but they did not become victims. Apparently already several times he and his friends to transact on the site. In that place there is always a Acang-Acang ${ }^{16}$ that they already know each other. Although in fact they were afraid, but they (Mulsim traders) is always calling to transact. By the time they are talking to each other and ask prices, a sudden large explosive bombs (high explosive) reads, an explosion of unknown origin. They then split up immediately ran back to their respective communities to save themselves. The explosion, making them split up for the day. But the next day they again meet and pay the price of oranges which yesterday had been taken. For both brothers, no longer feel worried and scared meets, even mutual trust is already accustomed to them.

At least, papalele have proved that the peace must receive attention. Therefore, long before the riots, among papalele and merchant relationships already established and to know each other. So that the incidence of violence is not enough to make them split up. A long-standing relationship and continue to cling, reinforced by the consideration that Christians are brothers. The strength of your relationship not only guided by purely economic motives, but it will be full of local values are still deeply embedded. The strength of the local norms and values have been firmly entrenched in the mind, especially about the meaning of 'the basudara - itself reportedly' as the value of their ancestors. Therefore, trade is not just

16 During the conflict of, the symbols of separation between Islam-Christian was created clearly. The term of "Acang” is from 'Hasan' for Islam and “Obed” from 'Roberth' for Christian. (Pariela Tony, 2008:88 and Gatra Magazine 2001). 
looking for an economical advantage, but the value of fraternity (local) held also put forward in a state of conflict. Although sometimes papalele and merchants often receive misleading issues when going to meet at the border. Issues are intentionally exhaled so as to make the atmosphere more tense. Issues are then often used to scare the public to avoid meetings and transactions, so that the instability of the security situation remains durable.

Courage meetings and transaction among papalele and traders are because of mutual trust. In certain situations, the aspect of trust does have risks, risks that sometimes occur unexpectedly before. Throughout the belief, it is really implemented and in accordance with the agreement, then avoid the risk of bad and vice versa. They have reaffirmed the identity of localities to build peace. Naturally peace is not the result of social engineering, but arises from the awareness of the importance of a sense of belonging (Al Qurtuby 2013).

\section{CONCLUSION}

Papalele perceived positive effects of regular meetings between them and the traders during the conflict. The intensity of regular meetings between the traders and papalele further improves relations and mutual trust which is the high one to the other. They no longer feel worried and afraid to meet. They do not make religion, ethnicity, race, as a separator. But these differences become strengths and are shown to maintain local identity as integral tool of life as brothers (the basudara).

In the process of building peace, trust capital is one of the most important aspects. Although sometimes it is vulnerable because of the pressure group, but confidence in the neighbor relations should take precedence. Experience to build the trust builds in an atmosphere of conflict must be upheld and maintained.

\section{REFERENCES}

Abdelal, R and Herrera, Y.M., 2001. Treating Identity as A Variable: Measuring the Content, Intensity, and Contestation of Identity. Paper pre- pared for presentation at APSA, August 30 September 2, 2001, San Francisco.

Adam, J. and Peilouw, L., 2008. Internal displacement and household strategies for income generation: A case study in Ambon, Indonesia. Social Development Issues, 3o(2), pp.78-89.

Adam, J., 2008. Downward social mobility, prestige and the informal economy in post-conflict Ambon. South East Asia Research, 16(3), pp.461-479.

Al Qurtuby, S., 2013. Peacebuilding in Indonesia: Christian-Muslim Alliances in Ambon Island. Islam and Christian-Muslim Relations, 24(3), pp.349-367.

Benwell, B and Stoko, E. 2006. Discourse and Identity. Edinburgh University Press Ltd 22 George Square, Edinburgh.

Berger, P.L. and Luckman, T., 1990. Tafsir Sosial Atas Kenyataan: Risalah tentang Sosiologi Pengetahuan. Penerbit PT Pustaka LP3ES, Jakarta.

Burke P.J. and Stets, J.E., 2009. Identity Theory. Oxford University Press.

Casey, T. and Dustmann, C., 2009.Immigrants' Identity, Economic Outcomes, and the Transmission of Identity across Generations. Discussion Paper Series CDP No 23/o9. Centre for Research and Analysis of Migration. Department of Economics, University College London Drayton House, 30 Gordon Street, London $\mathrm{WC}_{1} \mathrm{H}$ oAX.

Castlle, M., 1997. The Information Age: Economy, Society and Culture. II. The Power of Identity". Blackwell Publisher, Oxford UK.

Chen, Y. and Li, X.S., 2005. Measuring Identity. Department of Economics, University of Michigan, Michigan.

Commission Research Paper. 2003. Social Capital: Reviewing the Concept and Its Policy Implications. Commonwealth of Australia.

Dasgupta, P. and Serageldin, S., 200o. Social Capital; A Multifaceted Perspective. The World Bank, Washington D.C.

Davis J.B., 2006. Identity and individual economic agents: A narrative approach. University of Amsterdam and Marquette University. University of Stirling October 2005 SCEME workshop. Electronic copy available at: http://ssrn. com/abstract $=1151325$.

Duncan, C.R., 2005. The other Maluku: chronologies of conflict in North Maluku. Indonesia, (8o), pp. $53-80$

Grootaert, C., April 1998. Social Capital: The Missing Link? The World Bank Social Development Family, Environmentally and Socially Sustainable Development Network, Social Capital Initiative, Working Paper No. 3.

Hasbulla, J., 2006. Social Capital; Menuju Keunggulan Budaya Manusia Indonesia. Penerbit MRUnited Press. Jakarta.

Ihalauw J.J.O.I., 2004. Bangunan Teori, Edisi Milenium. Katalog Dalam Terbitan (KDT). Universitas Kristen Satya Wacana Salatiga, Salatiga. 
Inkpen, A.C. and Tsang, E.W., 2005. Social capital, networks, and knowledge transfer. Academy of management review, 30(1), pp.146-165.

Jenkins, R., 2008. Social Identity. 3rd edition published by Routledge 2 published in the USA and Canada, New York.

Laurence, J., 2009. The effect of ethnic diversity and community disadvantage on social cohesion: A multi-level analysis of social capital and interethnic relations in UK communities. European Sociological Review, 27(1), pp.70-89.

Leonard, M., 2004. Bonding and bridging social capital: Reflections from Belfast. Sociology, 38(5), pp.927-944.

Lin, N., 1976. Foundation of Social Research. Departement of Sociology State University New York. Mc Graw-Hill Book Company.

Loveband, A. and Young, K., 20o6. Migration, provocateurs and communal conflict: the cases of Ambon and West Kalimantan.

Mailoa, J.P., 2006. Kamus Bahasa - Harian Dialek Orang Ambon. Penerbit Kulibia Printing Jakarta.

Nee, V., 1998. Norms and Networks in Economic and Organizational Performance. Department of Sociology, 312 Uris Hall, Cornell University, Ithaca, NY. The American Economic Reviuw, Vol. 88 No. 2. Publish by American Economic Assosiation.

Pantoja. E., 2002. Qulitative Analysis of Social Capital: The Case of Community Development in Coal Mining Areas in Orissa, India". Within Christian Grootaert and Thierry van Bastelar "Understanding ad Measuring Social Capital: A Multi-disciplinary Tool for Practitioners". The World Bank Washington D.C.

Pariela, T.T., 2008 "Damai Di Tengah Konflik Maluku: Preserved Social Capital Sebagai Basis Survival Strategy". Penerbit Program Pascasarjana Studi Pembangunan Universitas Kisten Satya Wacana Salatiga.

Pilokoanu, R.T., 2010. Identitas Sosial: Suatu Kajian Sosiologis Orang Dayak Manyaan di Banjarmasin Kalimantan. Postgraduate Thesis. Universitas Kristen Satya Wacana, Salatiga.

Porritt J., 2002. The mission of Forum for the Future is to Accelerate the Building of a Sustainable Way of Life, Taking a Positive, Solutions oriented Approach. Sustainable Development is a Dynamic Process That Enables All People to Realise Their Potential and to Improve Their Quality of Life in Ways That Simultaneously Protect and Enhance the Earth's Life-Support
Systems". Changing Business April 2002. Forum for the Future's work with the business community

Prabaw, T.S., 2010. The Tourism Industry Under Crisis; The Struggle of Small Tourism Enterprise in Yogyakarta (Indonesia). Dissertation. Faculteit der Sociale Vrije University, Amsterdam.

Putranto, H., 2008. Wacana Pascakolonial dalam Masyarakat Jaringan. in "Hermeneutika Pascakolonial; Soal Identitas". (ed) Mudji Sutrisni dan Hendar Putranto. Kanisius, Yogjakarta.

Ritzer, G., 2004. Sociological Theory. Third Editon. By Mc Graw Hill. Inc. New York.

Serageldin, S. and Christian, G., 1999. Defining Social Capital: An Integrating View dalam Dasgupta, Partha and Ismail Serageldin. Social Capital A Multifaceted Perspective, The World Bank, Washington D.C.

Sholeh, B., 2013. The Dynamics of Muslim and Christian Relations in Ambon, Eastern Indonesia. International Journal of Business and Social Science, 4(3), pp.303-311.

Soegijono, S.P., 2011. Papalele: Potret Aktivitas Komunitas Pedagang Kecil di Ambon. Fakultas Ekonomika dan Bisnis UKSW, Salatiga.

Souisa, N.N., 1999. Papalele: Ajang Hidup Berteologi Perempuan Ambon, Suatu Kajian Sosial Teologis tentang Posisi dan Peranan Perempuan Papalele di Jemaat-Jemaat Kristen Pinggiran Ambon. Postgraduate Thesis. Magister Sosiologi Agama UKSW Salatiga. Unpublished..

Suwond, K.N. and Marwata. 2008 Makna Penelitian Kualitatif Phenomenalogi. Program Pascasarjana - Doktor Studi Pembangunan Universitas Kristen Satya Wacana, Salatiga.

Turner, R.K., 2010. Ecological-economic analysis of wetlands: scientific integration for management and policy. Ecological Economics, 35(1), pp.7-23,

Widén-Wulff, G. and Ginman, M., 2004. Explaining knowledge sharing in organizations through the dimensions of social capital. Journal of information science, 30(5), pp.448-458.

Wilardjo, L., 1994. Studi Kasus: Sebuah Panduan Praktis. Satya Wacana University Press and PT Gramedia Widiasarana, Jakarta.

Mass Media Information (printed):

Kompas Newspaper, 5 Mei 1999.

Tempo Magazine 20 February 2000

Weekly Magazine Gatra 18 August 2001

Weekly Magazine Gatra 25 August 2001 